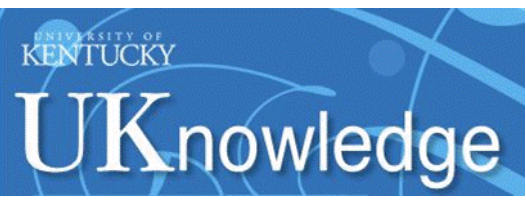

University of Kentucky

UKnowledge

3-2014

\title{
Soybean Variety Selection
}

\author{
Chad Lee \\ University of Kentucky, chad.lee@uky.edu \\ Carrie Ann Knott \\ University of Kentucky, camurp2@uky.edu \\ Edwin L. Ritchey \\ University of Kentucky, edwin.ritchey@uky.edu
}

Follow this and additional works at: https://uknowledge.uky.edu/anr_reports

Part of the Agriculture Commons, and the Environmental Sciences Commons

Right click to open a feedback form in a new tab to let us know how this document benefits you.

\section{Repository Citation}

Lee, Chad; Knott, Carrie Ann; and Ritchey, Edwin L., "Soybean Variety Selection" (2014). Agriculture and Natural Resources Publications. 133.

https://uknowledge.uky.edu/anr_reports/133

This Report is brought to you for free and open access by the Cooperative Extension Service at UKnowledge. It has been accepted for inclusion in Agriculture and Natural Resources Publications by an authorized administrator of UKnowledge. For more information, please contact UKnowledge@lsv.uky.edu. 


\section{Soybean Variety Selection}

Soybean variety selection is one of the most important and Omost difficult management decisions a producer must make each year. It takes careful identification of the problems and needs of the production system. When done properly it increases the chance the variety will reach its full yield potential while eliminating costs for unnecessary traits, resulting in highly profitable returns.

\section{Yield Potential}

Yield potential is typically the first trait examined when selecting soybean varieties. It is also the most complicated because yield potential is very sensitive to environmental differences. To provide unbiased, scientifically sound estimates of soybean variety yield the University of Kentucky evaluates the yield potential of soybean varieties each year in replicated trials at multiple locations in the Kentucky. The soybean variety test reports are available at http://www.uky.edu/Ag/GrainCrops/ varietytesting.htm\#ArchivedReports. Similar tests are also conducted by surrounding states.

Soybean Variety Performance Tests are invaluable for variety selection, because we cannot predict growing conditions for the upcoming season. Variety performance over multiple locations and years provides the best estimate of variety performance in different growing conditions. In general, a variety that performs as well as (i.e. is statistically similar to) the highest yielding variety across several locations and years tolerates a wide range of growing conditions. For this reason, the Kentucky Soybean Variety Performance Tests State Summary data reports data for one year, two years, and three years.

The key to determining which variety should be selected depends upon individual production systems, such as maturity group desired, disease resistance needed, and weed-control program desired. Before examining variety performance data, you must understand the type of variety needed to maximize yield. Selecting a variety or varieties should be based upon multiple years and locations of data. Varieties that consistently yield the highest, regardless of environmental conditions, should be selected.

As an example, an excerpt from the 2013 Soybean Variety Performance Tests, State Summary, is included as Table 1 (Group III) and Table 2 (Group IV). Variety names have been changed, but the yield performance data has not. The three years in this example had different growing conditions. Year 1 was a good season with ample and timely rainfall. Year 2 was extremely hot and dry early resulting in very low yields, especially for the early-maturing varieties. Year 3 was closer to average where some dry weather occurred during seed fill, but yields were typical. Varieties that performed well across these
Table 1. Excerpt from the 2013 Kentucky Soybean Variety Performance Tests, State Summary, for Maturity Group III.

\begin{tabular}{|c|c|c|c|}
\hline \multirow[b]{2}{*}{ BRAND VARIETY* } & \multicolumn{3}{|c|}{ YIELD (BU/AC)A } \\
\hline & ONE YEAR & 2 YEARS & 3 YEARS \\
\hline \multicolumn{4}{|c|}{ MATURITY GROUP III (relative MG 3.0-3.9) } \\
\hline SDX 3027 & 67.7 & & \\
\hline LDW 7935 & 67.1 & 57.8 & \\
\hline ITR 524 & 66.6 & & \\
\hline WGS $6960^{C}$ & 66.2 & 54.6 & 51.9 \\
\hline ITR 7409 & 64.6 & & \\
\hline VNR 1837 & 63.7 & 55.6 & 52.8 \\
\hline ITR 164 & 63.7 & 56.1 & \\
\hline OYN 4147 & 63.2 & & \\
\hline KNX 7921D & 61.6 & 52.5 & 50.3 \\
\hline ITR 4180 & 61.4 & 52.1 & 50.1 \\
\hline ORG 4118 & 61 & & \\
\hline ENS 6418 & 60.7 & & \\
\hline RRSS 3915 & 60.6 & & \\
\hline CCDF 2687 & 59.6 & & \\
\hline SAD 2177 & 58.8 & 53.3 & 50.5 \\
\hline WGS 6877 & 58.6 & & \\
\hline KLM 231 & 57.7 & & \\
\hline SDX 1924 & 57.3 & & \\
\hline GROUP III AVERAGE & 62.7 & 54.6 & 51.1 \\
\hline LSD (0.10) & 7 & 4.2 & 3.8 \\
\hline C.V. & 8.3 & 7.5 & 7.9 \\
\hline
\end{tabular}

A Within a maturity group, shaded yields are not significantly different (0.10) from the highest yielding cultivar (bold data) of that maturity group and year column.

B 2013 data collected in Caldwell, Calloway, Fayette, Hardin, and Simpson county locations; 2012 data collected in Caldwell, Calloway, Daviess, Fayette, and Simpson county locations; 2011 data collected in Caldwell, Calloway, Fayette, McLean, and Warren county locations.

c Yellow highlighting identifies soybean varieties with consistent performance for the one-, two-, and three-year averages.

D Blue highlighting identifies soybean varieties with consistent performance for the one- and three-year averages.

*Variety names have been changed. For complete variety performance data visit the Soybean Variety Testing Web site: http://www2.ca.uky.edu/ pss/index.php? $p=663$.

three diverse seasons are considered to have yield stability. Out of the Group III varieties tested, there were two varieties that consistently produced high yields: WGS 6960 and VNR 1837. For Group IV soybean varieties tested, MRA 6457, KLM 9699, WGS 5959 consistently produced high yield (Table 2). These varieties should tolerate a wide range of growing conditions and would be good variety choices based upon the consistently high yields in very different growing conditions. 
As irrigation increases in Kentucky, farmers will be interested in choosing varieties for irrigation. In general, a variety that performs well across many environments should perform well under irrigation. Because of the extreme drought in Year 2 in our example, a producer may disregard much of the two-year data when choosing varieties. However, almost no irrigation system performs at a level where all water stress is removed. So, the two-year data should only be disregarded if the producer can guarantee no lack of water from irrigation (no down time, no power outages, no limits to water, etc.). If the producer makes this assumption, then additional varieties that performed well in the one-year and three-year data are KNX 7921 and ITR 4180 for Group III and HGP 9689 for Group IV.

Yield potential is one of many factors that should be evaluated when selecting soybean varieties. Ensuring that a soybean variety is resistant to a disease that has been a problem on farm or in the county is essential to maximizing yield potential. On the other hand, ensuring that you are not paying for costly traits that are not needed in the area will also help maximize profitability. Bottom line: Clearly defining and understanding the challenges and problems of any production system will result in better variety selection and in turn higher profitability.

\section{Soybean Maturity}

Soybean flowering is triggered mostly by photoperiod. Time of planting and temperature will affect flowering to some degree, but the overwhelming trigger for flowering is the length of the night or darkness. A soybean variety that matures rather quickly or "early" is sensitive to a shorter night and requires fewer hours of darkness to begin flowering, whereas a slowermaturing or "late-maturing" variety requires more hours of darkness to begin flowering.

Soybean varieties are divided into ten Maturity Groups across North America ranging from 000 to VIII. Soybeans in Group 000 are the earliest-maturing varieties and Group VIII varieties mature the latest. The early-maturing varieties are adapted to the northern United States and Canada while the late-maturing varieties are adapted to the southern United States. Historically, Groups III, IV and V are best suited for Kentucky. When planted on May 1 in Kentucky, soybeans in Group III will flower about nine days before soybeans in Group IV, which will flower about eight days before soybeans in Group V. The differences in flowering shorten as soybeans are planted later.

As more soybean varieties have been developed, a numerical system has been adopted to further describe the relative maturity of soybean varieties within a maturity group. For example, relative maturities of 3.0 to 3.9 are within Group III; therefore, when planted on the same day a 3.0 variety will flower sooner than a 3.9 variety. Similarly relative maturities of 4.0 to 4.9 are in the Group IV and varieties designated as 4.0 will mature sooner than 4.9.

The majority of soybean varieties grown in Kentucky are Group III and IV with relative maturities ranging from 3.0 to 4.9. Some producers in the far western part of the state have grown Group V soybeans with a relative maturity of 5.0 and greater. In addition, there have been a few acres of Group II
Table 2. Excerpt from the 2013 Kentucky Soybean Variety Performance Tests, State Summary, for Maturity Group IV.

\begin{tabular}{|l|c|c|c|}
\hline \multirow{2}{*}{ BRAND VARIETY* } & \multicolumn{3}{|c|}{ YIELD (BU/AC) } \\
\cline { 2 - 4 } & ONE YEAR & 2 YEARS & 3 YEARS \\
\hline \multicolumn{3}{|c|}{ MATURITY GROUP IV EARLY (relative MG 4.0-4.5) } \\
\hline MRA 6457C & $\mathbf{7 1 . 4}$ & 58.5 & $\mathbf{5 7 . 0}$ \\
\hline SEH 3490 & 68.5 & & \\
\hline RRSS 8498 & 68.3 & $\mathbf{6 0 . 0}$ & \\
\hline DGM 8978 & 67.9 & & \\
\hline KLM 9699 & 66.6 & 56.5 & 55.4 \\
\hline CCDF 5617 & 66.6 & & \\
\hline SAD 9090 & 66.6 & & \\
\hline WGS 5959 & 65.9 & 57.2 & 56.3 \\
\hline CCDF 8181 & 65.5 & & \\
\hline HGP 9689D & 65.4 & 55.8 & 53.8 \\
\hline GSL 3853 & 65.3 & & \\
\hline WGS 3724 & 65.0 & 55.8 & \\
\hline DGM 3033 & 64.9 & & \\
\hline HGP 8246 & 64.8 & 56.6 & 55.1 \\
\hline WGS 3883 & 64.4 & 55.1 & \\
\hline ITR 9088 & 64.3 & 56.2 & 55.5 \\
\hline SDX 6646 & 63.8 & 54.5 & 55.3 \\
\hline SDX 6059 & 62.9 & 56.3 & 53.5 \\
\hline GROUP IV EARLY & $\mathbf{6 3 . 3}$ & $\mathbf{5 5 . 2}$ & $\mathbf{5 4 . 0}$ \\
\hline AVERAGE & & & \\
\hline C.10) & 6.3 & 4.0 & 3.5 \\
\hline A Win a maty & 7.3 & 7.3 \\
\hline
\end{tabular}

A Within a maturity group, shaded yields are not significantly different (0.10) from the highest yielding cultivar (bold data) of that maturity group and year column.

B 2013 data collected in Caldwell, Calloway, Daviess, Fayette, Hardin, and Simpson county locations; 2012 data collected in Caldwell, Calloway, Daviess, Fayette, and Simpson county locations; 2011 data collected in Caldwell, Calloway, Fayette, McLean, and Warren county locations.

c Yellow highlighting identifies soybean varieties with consistent performance for the one-, two-, and three-year averages.

D Blue highlighting identifies soybean varieties with consistent performance for the one- and three-year averages.

*Variety names have been changed. For complete variety performance data visit the Soybean Variety Testing Web site: http://www2.ca.uky.edu/ pss/index.php? $p=663$.

soybeans grown with relative maturities of 2.5 to 2.9. These Group II soybeans are planted with the goal of harvesting early to capture historically higher commodity prices in August and September. Another advantage of using early maturing varieties is the possible avoidance of drought conditions in late July or August.

\section{Relative Maturity and Planting Date}

Relative maturities of 4.0 to 5.0 are considered full-season in far Western and southern Kentucky, which includes the Purchase Area and areas south of the Western Kentucky Parkway. Typically, full-season soybeans are planted from mid-April to early-June in these areas. In Northern and Eastern Kentucky, which would include the areas north of the Western Kentucky Parkway, the central Bluegrass and Eastern Kentucky, full-season varieties have relative maturities from about 3.5 to 4.5. Typical planting dates for full-season soybean varieties in Northern and Eastern Kentucky are late-April to early-June (Figure 2). 


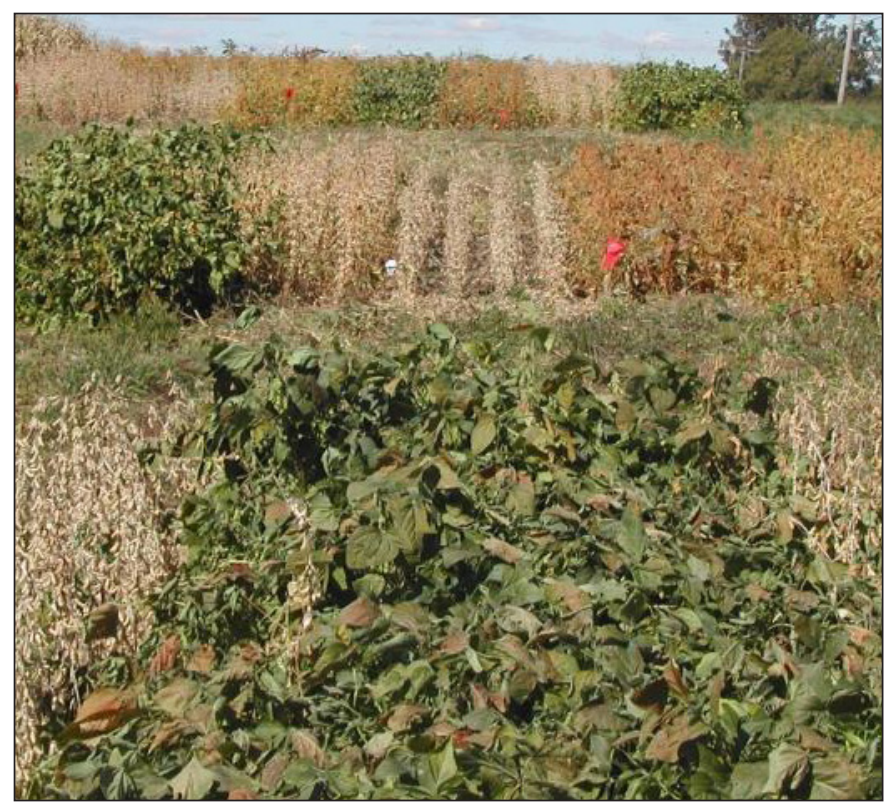

Figure 1. A soybean maturity group study at Lexington, KY. The dark green soybean crops in the center were Maturity Group V and damaged from a fall frost.

Although, full-season soybean varieties have a very large planting window, early- and late-maturing soybeans must be planted early (Figure 2). For Western and southern Kentucky, early-maturing (2.5 to about 3.9 ) and late-maturing soybeans (about 5.0 to 5.5) should be seeded mid-April to mid-May. For Northern and Eastern Kentucky, early-maturing soybeans (about 2.0 to 3.5) and late-maturing soybeans (about 4.6 to 5.0) should be planted late April to mid-May (Figure 2). Planting full-season soybeans before July will help ensure that maximum yield potential is possible. If full-season soybeans must be planted in July, consider reducing the relative maturity of the planted varieties by 0.5 to 1.0 point to allow soybean maturation to occur before the risk of early frost events.

Double-crop soybeans are planted after wheat is harvested. Most double-crop soybeans are planted between early-June and early-July. If for any reason double-crop planting extends beyond early-July, then a producer may want to reduce relative maturity by 0.5 to $1.0 \mathrm{in}$ an attempt to reduce the risk of frost damage in the fall (Figure 2).

Because of variability in weather from year to year, earlymaturing varieties may yield the best one year and late-maturing varieties may yield best the next. Planting a range of relative maturities reduces the risk that environmental factors will negatively impact yield of the entire soybean crop.

\section{Determinate and Indeterminate Types}

The majority of soybeans grown in Kentucky are indeterminate, meaning that once flowering begins, the main stem continues to produce new nodes and leaves. Flowering normally begins near the bottom of the main stem and continues upward as the plant continues to grow. At some point (usually about the time seed production starts), vegetative growth will stop and reproductive growth will continue. Some soybean varieties in Group $V$ are determinate, meaning that most of the vegetative growth is complete by the time flowering begins. Determinate soybean varieties are typically larger than indeterminate varieties when flowering begins. However, there are very few determinate varieties suitable to Kentucky, so effectively all of the varieties grown in Kentucky are indeterminate. Whether an indeterminate or determinate, most soybean fields need to capture about 95 percent light interception when flowering starts or shortly after first flower. Most years, capturing 95 percent light is easier to accomplish in 15 -inch rows than 30 -inch rows.

\section{GM0 or Conventional Soybean}

For many decades, soybean breeders have introduced favorable traits into soybean varieties using traditional plant breeding techniques. Originally, soybean (Glycine max) and closely related species were the sources of genes that conferred favorable traits. More recently plant breeders are using genetic engineering, which inserts genes from unrelated species into soybeans, and traditional techniques to develop improved varieties with desirable traits (genes). Plants that have been genetically engineered are referred to as Genetically Modified Organisms (GMO), while soybeans varieties that have not undergone genetic engineering are referred to as conventional or non-GMO varieties.

Figure 2. Soybean relative maturities and general planting dates for Kentucky.

Western and Southern Kentucky

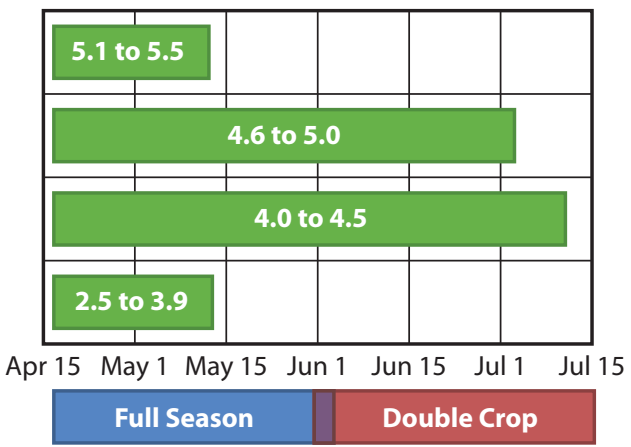

Northern and Eastern Kentucky

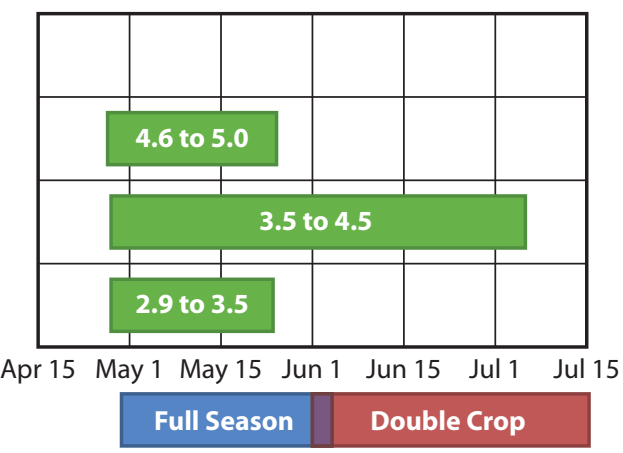


In the past 20 years most soybean varieties have transitioned from conventional to GMO varieties. The most common GMO varieties in the United States are resistant to herbicides. Varieties containing these traits are patented, and those patents do not allow farmers to save seed for future plantings. As a result, farmers who chose to purchase and grow GMO soybeans are agreeing to buy new GMO soybean seed each year.

Certain soybean buyers purchase only conventional or nonGMO soybeans, especially for foreign markets. In some markets, buyers pay a premium for conventional seed. The disadvantages of conventional varieties are that they may yield about 10 percent less than GMO varieties and require more intensive weed management programs. Some conventional varieties have been patented, therefore saving seed for future planting may not be allowed.

\section{Herbicide Tolerance Traits}

At this point, the majority of soybean varieties sold in Kentucky contain one genetically-engineered herbicide tolerance trait. The brand names of the three most common herbicide tolerant traits are Roundup Ready, Roundup Ready 2 Yield and Liberty Link (Table 3). Roundup Ready (RR) and Roundup Ready 2 Yield (RR2) tolerate glyphosate herbicide, the active ingredient in Roundup brand herbicides and other brands. Liberty Link (LL) soybeans tolerate glufosinate herbicide, the active ingredient in Liberty or Ignite. These three brands of soybean varieties are GMO varieties. Another herbicide-tolerant class of soybeans is sulfonylurea-tolerant soybeans (STS). These STS varieties are conventional varieties, meaning they were developed using traditional plant breeding selection methods from existing soybean genotypes. All STS soybean varieties tolerate sulfonylurea herbicides, such as Synchrony XP, but are not a product of genetic engineering. Some soybean varieties contain both STS and Roundup Ready traits; these varieties are considered GMO varieties because they contain the Roundup Ready technology.

\section{Disease Resistance}

The majority of seed companies report disease resistance ratings for phytophthora root and stem rot, sudden death syndrome, soybean mosaic virus and stem canker. Some are beginning to report resistance to frogeye leaf spot. Fields with known histories of either phytophthora root and stem rot or sudden death syndrome are likely to have those diseases again; therefore resistant soybean varieties with excellent yield potential should be chosen for those fields.

Fields where fog or mist is often present each morning, especially bottom fields, are likely to have problems with frogeye leaf spot. Soybean varieties with resistance to frogeye leaf spot in addition to excellent yield potential are preferred in those fields.

Selecting disease resistant soybean varieties can be extremely complex depending on the disease targeted. For detailed descriptions and considerations of common soybean diseases in Kentucky refer to the University of Kentucky's Plant Pathology Extension Publications for Soybean Diseases: http://www2. ca.uky.edu/agcollege/plantpathology/extension/pubs.html.

\section{Nematode Resistance}

Soybean cyst nematode ( $\mathrm{SCN}$ ) is the nematode that causes yield losses in Kentucky. It is found in all soybean producing counties of Kentucky. Northern and southern root knot nematodes also occur in Kentucky. Fortunately, northern and southern root knot nematodes have a very limited distribution thus limited yield losses occur in Kentucky due to these two nematodes. Another nematode, reniform nematode, has not been found in Kentucky at this time.

Most soybean varieties sold in Kentucky are resistant to SCN. However, the level of resistance to $\mathrm{SCN}$ can vary by variety. For more information on this complex issue, refer to the University of Kentucky's SCN Web site (http://www.uky.edu/SCN) and the SCN Management Recommendations for Kentucky (http://www2.ca.uky.edu/agcollege/plantpathology/ext_files/ PPFShtml/PPFS-AG-S-24.pdf).

\section{Standability and Shattering Potential}

Historically, soybean lodging was a problem with certain varieties, thus standability ratings were a concern. Today, the majority of standability problems are related to management decisions. For example, very high plant populations and row widths of 7.5 inches or less increase the likelihood of lodging. In general, larger plants associated with later-maturing varieties are more prone to lodging.

Shattering loss was a problem with older varieties but is less of an issue today. Shattering among current soybean varieties is most affected by weather conditions. The weather after seed have reached physiological maturity are drying to harvest maturity causes more shattering problems than genetics. Timely

Table 3. Herbicide tolerance traits available for sale in Kentucky.

\begin{tabular}{|l|l|l|c|c|}
\hline \multirow{2}{*}{ Brand Name } & Herbicide Tolerated & \multicolumn{1}{c|}{$\begin{array}{c}\text { Variety } \\
\text { Classification }\end{array}$} & $\begin{array}{c}\text { Year } \\
\text { Released }\end{array}$ \\
\cline { 2 - 4 } & $\begin{array}{l}\text { Common } \\
\text { Name }\end{array}$ & $\begin{array}{l}\text { Brand Name } \\
\text { Example }\end{array}$ & GMO1 & 2009 \\
\hline Liberty Link & glufosinate & Liberty & GMO & 1996 \\
\hline Roundup Ready & glyphosate & Roundup & GMO & 2009 \\
\hline Roundup Ready 2 Yield & glyphosate & Roundup & Conventional2 & 1994 \\
\hline STS (Sulfonylurea-Tolerant Soybeans) & sulfonylurea & Synchrony XP & S \\
\hline
\end{tabular}

1 Genetically modified organism (GMO) breeding methods included inserting foreign gene segment to confer resistance to herbicide applications using biotechnology techniques.

2 Conventional breeding methodologies were utilized to confer resistance to herbicide applications. 
harvest can also help to maximize soybean yields. Significant shattering loss can occur once soybean varieties have reached physiological maturity and harvest is delayed due to weather conditions or other variables. Stressful weather conditions near harvest could cause shattering. Extended damp periods during seed drydown and soften pods. If that is followed by warm weather that allows the pods to dry out, they may shatter.

\section{Seed Quality and Seed Size}

\section{Seed Germination}

Seed germination is the percent of seeds that are capable of producing a normal seedling within 7 to 10 days in ideal conditions $\left(68^{\circ}\right.$ to $86^{\circ} \mathrm{F}$ or $20^{\circ}$ to $\left.30^{\circ} \mathrm{C}\right)$. In Kentucky all soybean seed sold in one pound containers or larger must be labeled with a tag that lists germination percentage along with other information about the seed. Most soybean seed sold in Kentucky has a germination of at least 90 percent. However, germination is affected by its production environment and seed with less than 90 percent germination may be sold in years following stressful growing seasons or when seed supply is limited.

Because it varies among seed lot of a single variety, germination should be considered when calculating seed rates. For example, if a producer wants to plant 120,000 seeds per acre and the seed lot has 95 percent germination, then the producer needs to plant 126,316 seeds per acre to adjust for germination $(120,000 / 0.95=126,316)$. If the seed lot has 80 percent germination, then the producer needs to plant 150,000 seeds per acre $(120,000 / 0.80=150,000)$. If seeding rates are not adjusted for germination low plant populations can result. For example, if a producer simply plants 120,000 seeds per acre then the population will be 114,000 plants per acre for seed with 95 percent germination and only 96,000 for 80 percent germination.

\section{Seed Vigor}

Germination percentage reported on the seed tag will predict emergence when soybean seed is planted into ideal conditions. However, soybean seed is not always planted into ideal conditions. In that case, seed vigor provides an indication of performance when soil conditions are not ideal. Two seed lots with identical standard germination can have differences in seed vigor.

A seed vigor test assesses the germination rate of a seed lot under stressful conditions. Germination of seed following accelerated aging is the most common test of vigor in soybean. Seeds are heated to high temperatures in an artificial environment before germination is measured.

A cold germination test involves planting seeds in a soil/sand mixture and kept at $50^{\circ} \mathrm{F}\left(10^{\circ} \mathrm{C}\right)$ for seven days and then moved into warmer temperatures for about five days. Seed vigor is not reported on seed tags, but could be obtained by submitting seed samples to a seed testing laboratory, such as the University of Kentucky Regulatory Services Seed Testing facility.

\section{Seed Treatments}

Almost all soybean seed is sold with some type of seed treatment. The seed treatments may contain a mix of fungicides, insecticides, inoculum and biological or other compounds. The fungicide seed treatments might be beneficial when seed are planted into disease prone cool, wet soils, especially if seed germination is marginal. Insecticide seed treatments may be beneficial when cool conditions slow plant growth. Bradyrhizobium japonicum is necessary if a field has not been in soybean for the past three to five years or if the previous soybean crop had poor nodulation. Some evidence says that fields saturated for extended periods during the winter have lower populations of Bradyrhizobium. Soybeans planted into these fields can benefit from a new inoculation.

Other compounds are intended to stimulate plant growth or plant defense systems. Studies on these compounds are limited. In soils with a pH less than 6.2, molybdenum (Mo) should be added to the seed. Mo, usually applied as sodium molybdate, can kill B. japonicum. If a field requires both Mo and the inoculant, then soybean seeds treated with both should be planted immediately after treatment. Another option to reduce B. japonicum mortality is to plant the inoculated soybean and then apply Mo to the soil in a separate operation.

\section{Soybean Seed Size}

Soybean seed size varies from about 2,500 to 3,500 seeds per pound. Little relationship exists between soybean seed size planted and the subsequent soybean seed at harvest. Environment affects final seed size more than genetics. When soybean seed is sold by the pound, smaller seeds would cost less per seed than larger seeds. Many soybean varieties are now sold on a unit basis, meaning that about 140,000 seeds are being sold for a set price regardless of seed size.

For more information on seeding rates, seeding dates and depths, consult AGR-130: Soybean Planting in Kentucky.

\section{Summary}

Soybean variety selection is essential to maximize profitability. Each year new soybean varieties enter the market and older varieties leave the market, which greatly complicates variety selection decisions. Carefully selecting soybean varieties that possess disease tolerance, nematode tolerance, maturity, and the yield potential needed for individual production systems will result in the most profitable returns each year. 


\section{Resources}

Hershman, D. E. 2011. 2012 Soybean Cyst Nematode (SCN) Management Recommendations for Kentucky. University of Kentucky Cooperative Extension Service Publication PPFS-AG-S-24.

Hershman, D. E. 2003. Soybean Diseases Control Series: Are We Missing Opportunities? Part 2: Soybean Sudden Death Syndrome. PPFS-AG-S-14.
Hershman, D.E. and P.E. Bachi. 2010. Soybean: early planting and disease. University of Kentucky Cooperative Extension Service Publication. PPFS-AG-S-22.

Kentucky Soybean Variety Performance Tests Bulletin Website (University of Kentucky Department of Plant and Soil Sciences): http://www2.ca.uky.edu/pss/index.php?p=663.

Lee, C. and J. Herbek. 2011. AGR-130: Soybean Planting in Kentucky. University of Kentucky CooperativeExtension Service.

Soybean Cyst Nematode Website (University of Kentucky Department of Plant Pathology): http://www.uky.edu/SCN.
Mention or display of a trademark, proprietary product, or firm in text or figures does not constitute an endorsement and does not imply approval to the exclusion of other suitable products or firms. 